\title{
Legal Protection for Buyers Who Have A Good Letter in Purchase of Object Guarantee Based on Horizontal Separation Principles
}

\author{
Mohamad Rizky ${ }^{1}$, Tumbur Palti D. Hutapea ${ }^{2}$ \\ \{mohamadrizki88@yahoo.com \} \\ ${ }^{1,2}$ Law Doctoral Program Students Universitas Jayabaya Jakarta, Indonesia
}

\begin{abstract}
The principle of horizontal separation is a principle in the land law governed by customary law, regulated in Article 5 and Article 44 paragraph (1) of the Basic Agrarian Law. Based on this principle, the land is separated from all objects attached to it, such as buildings and trees. The problems discussed in this paper are first, how the existence of the principle of horizontal separation in the legal system in Indonesia. Second, how the government provides the concept of legal protection for buyers in good faith towards land objects in collateral. The results of the study note that the existence of the principle of horizontal separation in the legal system in Indonesia is not fully understood by the Indonesian people, especially rural communities.
\end{abstract}

Keywords: Legal protection, Buyer in good faith, principle of separation Horizontal.

\section{Introduction}

The principle of horizontal separation is the opposite of the principle of attachment which says buildings and plants are one unit with the land. In contrast, the principle of horizontal separation states that buildings and plants are not part of the land. The principle of horizontal separation is regulated in Article 44 paragraph 1 of Law Number 5 of 1960 concerning Basic Regulations on Agrarian Principles (UUPA). The implementation is a lease right for a building that is a person or legal entity rents land for another person's vacant or non-existent building by paying a sum of money as rent which amount is determined by agreement, for a certain period of time, and the tenant is given the right to build the building used for a certain period of time agreed by both parties.[1]

One case of the principle of horizontal separation is that if after the secondary rights of the land tenant expire, the holders of land ownership (Primary Rights) want to control the land itself. While there is a building that stands tall on the ground. In the process of building construction, the surface of the ground had previously been dug out to be planted with piles and various concrete as building foundations. If the building is demolished as stated in Law Number 28 Year 2002 concerning Buildings, such actions as well as efforts to reclaim land will be costly, making it inefficient.[2]

The application of the principle of horizontal separation in Indonesian land law provides for the separation between land ownership and what is underneath and below it, 
only those directly related to land use can be utilized. This limits the authority of the owner of the land rights in utilizing the land he owns, because the utilization of what is contained in the land and attached to it must be proven that it is and only related to the use of the land One case in point is that after the expiry of leasing a piece of land, the landowner wishes that the land owned by him will be used alone, while on that land a building or building will stand firm and it is impossible to be demolished generalized with the land. Thus, in the example of this case, the owner of the building / building (buyer in good faith) certainly feels disadvantaged by the desire of the landowner to control his own land. From this side the author will raise and discuss it in an international level Business Journal of Law, bearing in mind that this civil land case is interesting and the need for legal protection for buyers in good faith.

Therefore, the problem that will be discussed in this paper is first, how existence is related to the principle of horizontal separation in the legal system in Indonesia. Second, how the government provides the concept of legal protection for buyers in good faith over land objects in collateral. The purpose of this study is to better understand and understand the problems associated with the principle of horizontal separation. In line with the losses that will arise for buyers in good faith, the government and related agencies need to formulate the best solution to provide legal protection for buyers in good faith.

\section{Method}

This research method is a Legal Sociology research method, with an empirical approach that is supported by interviews with various interviewees.

\section{Results and Discussion}

In the practice of sticking to two different rights such as this it can be agreed that the secondary rights holder will hand over the building to the owner of the property right when the validity period of the secondary rights ends. However, landowners still lack the choice of what can be done with the property. In addition, it reflects the injustice of the old building owner if he who has struggled and spent money, time and energy to build and maintain the building, in the end must lose this right. For some people this kind of thinking seems influenced by capitalism. Actually the writer only put himself in the position of the owner of the Secondary Rights. If not forced by the situation through land legislation, then no one is willing to simply give up his property to someone else just because the secondary rights expire. For example, the Hilton Hotel has changed its ownership to the Sultan Hotel because of the inefficiency of the national land law, the HGB cannot be extended.[3]

The legal status of a building that has expired a period of time Secondary rights must also be considered. The Supreme Court Jurisprudence said that the holders of the old secondary rights will be given priority over the extension of the secondary rights. However, a loophole to this renewal obligation can occur. If someone has a bad intention and then submit a request for extension of the secondary rights on their own behalf and given the lack of proper registration of the land registration system in Indonesia, the issuance of the certificate of secondary rights in the name of the person in bad faith is not unusual. Problems arise, if the building was intended as a flat / condominium or shops, which are then divided into apartment units or kiosks. Each apartment unit owner holds rights called strata title based on the law, the strength is the same as the ownership rights in ordinary houses. No one should revoke this right, unless it is proven that the right was obtained illegally or revocation was carried out for social purposes. 
In this case, the regional government should decide not to extend the secondary rights (for example, the right to use, because state land can only be attached to use rights or management rights). Considering that the Regional Government intends to utilize the land and building itself or there are investors who can pay for the granting of secondary rights at a price higher than that offered by the manager. If this happens, the apartment or shop developer and the local government can be sued by the association of occupants or stall owners. The legal basis is that it has committed an act against the law because it has deceived consumers by selling stall / apartment units with strata title, even though the unit is located on the land use rights. At least this case example can show the principle of horizontal separation which has more disadvantages than benefits, because its existence can be used as a means of deceiving parties in good faith.

\subsection{The existence of the principle of horizontal separation in the legal system in Indonesia}

The principle of horizontal separation is the principle that is being enforced in the National Land Law, overriding the principle of attachment. In the principle of horizontal separation, buildings and plants on land are not part of the land so ownership of buildings and plants on a piece of land does not necessarily fall to the landowner. Legal action regarding land does not automatically include buildings and plants belonging to the landowner on it. If the legal action on the land is intended to cover the buildings and plants as well, then this matter must be explicitly stated in the deed that proves the legal action concerned.[4]

The panel of judges in their decision Number 337/Pdt/2014/PT.Smg, the judge decided not to accept the lawsuit against the Comparators on the grounds that the Appellants were not true contenders in the eyes of the law because even though there was a principle of horizontal separation that separated the land from the building above it, it has been stated in the previous decision that the comparators before the contenders are those who are not entitled to occupy the land of the object of execution and therefore the panel considers that the contenders are those who must vacate and hand over the land of the object of execution to the applicant for execution. Thus, when a person builds a building on a piece of land and has occupied the building for many years when the land is disputed at a later date and he loses in the land dispute, then he becomes the party who must carry out the decision by submitting the disputed land. Although there is a principle of horizontal separation that separates the disputed land from the buildings he has built which the building should be entitled to, he remains an unjustified party because he has erected a building on land to which he has no right to the land, so he must vacate and surrender the land to the rightful party.[5]

\subsection{Government Legal Protection for Buyers in Good Will of Land Objects under Collateral}

Legal protection for buyers in good faith is based on the Supreme Court Circular Letter Number 4 of 2016 concerning the Imposition of the Results of the 2016 Supreme Court Chamber Plenary Meeting as a Guideline for the Implementation of Duties for the Court, as follows:

1) Conducting sale and purchase of these land objects with procedures / procedures and valid documents as determined by the legislation, namely:

a) Land purchase through public auction or Purchase of land in the presence of a Land Deed Making Officer (in accordance with Government Regulation Number 24 of 1997 orPurchase of customary / unregistered land which is carried out according to the provisions of customary law.

b) Purchases are made at reasonable prices. 
2) Exercise caution by examining matters relating to the promised land object, including:

a) Seller is a person who has the right / has rights to the land which is the object of buying and selling, in accordance with proof of ownership, or

b) The land / object being traded is not confiscated, or

c) The object land being traded is not in security / mortgage status, or

d) For land that is certified, has obtained information from the BPN and a history of the legal relationship between the land and the certificate holder.

The requirements for letters $\mathrm{a}$ and $\mathrm{b}$ above are cumulative, so both must be implemented, not just one. In other words, a person can be said to be a good-faith buyer if he buys land in accordance with procedures / laws and regulations and has previously examined carefully the material facts (physical data) and the validity of the transfer of rights (juridical data) on the land he bought, before and on during the process of transferring land rights. If the criteria of the buyer in good faith have been met, even though in the future it is known that the land was purchased from an unauthorized person (unauthorized seller), then land that has been bought by the buyer in good faith cannot be contested by anyone.

The original landowner can only file compensation claims to unauthorized sellers, not to buyers in good faith. This is stipulated in the Supreme Court Circular Letter (SEMA) Number 7 of 2012. In item IX it is stated that 1) Protection must be given to buyers in good faith even though it is known that the seller is an unauthorized person (object of buying and selling land); 2) The original owner can only file a claim for compensation to unauthorized Sellers.

\section{Conclusion}

The existence of the principle of horizontal separation is regulated in Article 44 paragraph (1) of the Basic Agrarian Law (UUPA). As a land law regulation in Indonesia, UUPA must be national in terms of both formal and material. From a formal point of view, national land laws must be established by Indonesian law makers, made in Indonesia, compiled in Indonesian, applicable to all regions in Indonesia and covering all land in Indonesia. Meanwhile, in material terms, the form of objectives, conceptions, principles, systems and contents of the Basic Agrarian Law must be of a national nature.

Legal protection for the buyer in good faith is basically legal protection given to the buyer, because he obtained material rights based on good faith. That is, he does not know the defects or flaws of the (acquisition process) of the goods, as regulated in Article 531 of the Civil Code. This protection is given, even if the seller is not the person entitled to transfer the property rights to the Buyer as stipulated in Article 551 of the Civil Code.

It is recommended that the implementation of the principle of horizontal separation be more optimal socialized to all levels of society, so that in the practice of buying and selling or leasing land, the public can know the existence of the principle of horizontal separation, with a clear legal basis namely Article 44 paragraph (1) of the Basic Agrarian Law.

Buyers in good faith should apply the Precautionary Principle before carrying out a sale and purchase or land lease transaction (either HGU, HGB, or Right to Use) so that in the future after the land lease period ends, and when the lease period is extended, the owner of the Primary Right to the land not arbitrary control of the land which is its primary right, of course this will harm the good faith of the buyer in good faith. 


\section{Acknowledgments}

The author would like to thank profusely to all those who have helped and supported the completion of the writing of this journal, especially the authors thank the Chairman of the Doctoral Program / Postgraduate Director and thank the authors to the UNNES for providing facilities to join in the International Conference in ICESI 2020 UNNES.

\section{References}

[1] http://artikelddk.com/asas-pemisahan-horizontal-hukum-agrariauupa/.

[2] https://www.hukumonline.com/berita/baca/hol16703/beberapa-pemikiran-tentangasas-pemisahan-horizontal-dalam-pertanahan/

[3] https://www.hukumonline.com/berita/baca/hol16703/beberapa-pemikiran-tentangasas-pemisahan-horizontal-dalam-pertanahan/.

[4] Santoso, Urip, 2012, Hukum Agraria: Kajian Komprehensif, Jakarta, Kencana.

Devina, Dyah, 2017, Kriteria Pemisahan Asas Horisontal terhadap Penguasaan Tanah dan Bangunan, dalam Yuridika: Volume 32 No. 2, Mei-Agustus. 